DOI: $10.2478 /$ achi-2020-0006

\title{
OPTIMIZATION OF FERRIC CHLORIDE LEACHING PARAMETERS OF COPPER EXTRACTION FROM CHALCOPYRITE CONCENTRATE USING TAGUCHI METHOD
}

\author{
Tevfik Agacayak $^{\mathrm{a}^{*}}$ and Mohamed Taha Osman Abdelraheem Ahmed ${ }^{\mathrm{b}}$ \\ ${ }^{a}$ Department of Mining Engineering, Konya Technical University, Konya, \\ Turkey \\ ${ }^{b}$ Institute of Graduate Studies, Department of Mining Engineering, Konya \\ Technical University, Konya, Turkey
}

\begin{abstract}
Taguchi (L16) experimental design (DOE) was used to optimize the extraction process of copper from chalcopyrite concentrate statistically. A series of experiments involving leaching of copper by ferric chloride in a hydrochloric acidic medium were conducted. Process optimization of the experimental data was performed via statistical analysis. Analysis of variance (ANOVA) technique indicated that the most effective parameter was the stirring rate and the less effective parameter was the ferric ion concentrate. In this study, experimental parameters and their ranges were chosen as follows: solid-to-liquid ratio, 2 $\mathrm{g} / 500 \mathrm{~mL}$; ferric chloride concentration, $0.05 \mathrm{M}$; leaching temperature, $30{ }^{\circ} \mathrm{C}$; acid concentration, $0.5 \mathrm{M}$, and a stirring speed, $400 \mathrm{rpm}$. Under these conditions, copper extraction from chalcopyrite of approximately $89 \%$ were achieved.
\end{abstract}

Keywords: Chalcopyrite, acid leaching, ferric ion, Taguchi experimental design, Minitab 16.0 .

\section{Introduction}

Chalcopyrite, $\left(\mathrm{CuFeS}_{2}\right)$, is the most important copper mineral in nature. ${ }^{1,2}$ It is generally separated from associated gangue minerals by

\footnotetext{
*Tevfik Agacayak,e-mail: tagacayak@ktun.edu.tr / tevfik@selcuk.edu.tr
} 
flotation followed by conventional pyrometallurgical processes. About 80 $85 \%$ of the total world copper production accounts for pyrometallurgical processes. ${ }^{3,4}$ At the moment, hydrometallurgical processes have been suggested as a viable alternative method for metal extraction from lowgrade sulfide ores to overcome pollution problems involved in smelting process and due to low capital costs. ${ }^{5}$ Hidalgo et al., $(2018)^{6}$ reported that ferric oxidant has proven to be a viable oxidant for chalcopyrite leaching. There are other various reagents in the hydrometallurgical processing used as oxidative leaching agents of chalcopyrite concentrates such as cupric ions, oxygen, bacteria, dichromate ion $\left(\mathrm{Cr}_{2} \mathrm{O}_{7}{ }^{2-}\right)$ and hydrogen peroxide $\left(\mathrm{H}_{2} \mathrm{O}_{2}\right)^{7-10}$

Reactions between chalcopyrite and ferric chloride at an acid $\mathrm{pH}$ can be summarized as follows: ${ }^{6}$

$$
\begin{aligned}
& \mathrm{CuFeS}_{2}+4 \mathrm{FeCl}_{3} \rightarrow \mathrm{CuCl}_{2}+5 \mathrm{FeCl}_{2}+2 \mathrm{~S}^{0} \\
& \mathrm{~S}^{0}+6 \mathrm{FeCl}_{3}+4 \mathrm{H}_{2} \mathrm{O} \rightarrow \mathrm{SO}_{4}{ }^{2-}+6 \mathrm{Fe}^{2+}+8 \mathrm{H}^{+}+18 \mathrm{Cl}^{-} \\
& \mathrm{CuFeS}_{2}+16 \mathrm{FeCl}_{3}+8 \mathrm{H}_{2} \mathrm{O} \rightarrow \mathrm{CuCl}_{2}+2 \mathrm{H}_{2} \mathrm{SO}_{4}+17 \mathrm{FeCl}_{2}+12 \mathrm{HCl}
\end{aligned}
$$

Dutrizac $(1990)^{11}$ reported that the main reaction product during leaching in ferric chloride media is elemental sulphur although some sulphate also is produced. There have been many studies on the optimization of dissolution by Taguchi method. Bayca et al., (2018) ${ }^{12}$ studied the optimization of leaching parameters of aluminum hydroxide extraction from bauxite waste. Merad and Belkhouche (2019) ${ }^{13}$ studied the optimization of $\mathrm{Cu}(\mathrm{II})$ extraction in chloride medium by Aliquat 336. Copur et al., (2015) ${ }^{14}$ determined the optimum conditions for the extraction of copper from chalcopyrite concentrate into $\mathrm{SO}_{2}$ saturated water. Abali et al., $(2011)^{15}$ determined the optimum conditions for leaching of the leaching of dolomite are in hydrochloric acid solution. Çopur et al., (2004) ${ }^{16}$ studied the 
optimum conditions for the dissolution of roasted zinc sulfate in sulfuric acid solution.

The aim of this study was to optimize statistically the copper extraction from chalcopyrite concentrate using ferric chloride and hydrochloric acid. The effects of parameters on the extraction of copper were investigated by using the Taguchi experimental design.

\section{Materials and Methods}

\section{Materials}

In this study, sample of the chalcopyrite concentrate were taken from Cengiz flotation plant (Siirt, Turkey) was used. Chemical analysis of the sample was done by AAS (GBC SensAA model). The result of the average assay of copper concentrate was $12.59 \% \mathrm{Cu}$. Tests were conducted on sample at particle size of $100 \%$ passing 150 micron.

\section{Methods}

\section{Chalcopyrite leaching tests}

Experiments were conducted in A Pyrex beaker of 1L leach reactor placed in temperature-controlled water bath closed by a rubber cover. The temperature of 30 to $90{ }^{\circ} \mathrm{C}$ of the leach solution in a water bath thermostatically controlled with $\pm 0.2{ }^{\circ} \mathrm{C}$ sensitivity. Stirring was provided by a Heidolph RZR 2021 model mechanic stirrer equipped with a Tefloncovered propeller in the range of $0-400 \mathrm{rpm}$. The $\mathrm{HCl}$ and $\mathrm{FeCl}_{3}$ concentrations were in the range of $0.01-0.5 \mathrm{~mol} / \mathrm{L}$ and $0.01-0.1 \mathrm{~mol} / \mathrm{L}$, respectively. The liquid volume was kept constant $(500 \mathrm{~mL})$ during the experiments and the amount of solid was changed in the range of 1 to 5 grams. Analysis of copper in the leach solution was determined by atomic absorption. Distilled water and reagent grade chemicals were used for all required solutions. 


\section{Taguchi experimental design}

In this study, instead of trying all combinations of experiments, a number matrix was designed using orthogonal index table and factor levels giving the best performance characteristics were determined. Taguchi (L16) experimental design (DOE) was realized with the help of Minitab 16.00 program. Taguchi experimental design plan $\left(\mathrm{L}_{16}\left(4^{5}\right)\right)$ and the data obtained from the experiments are given in Table 1. The Taguchi method was provided to the experimental data and the signal to noise ratio $(\mathrm{S} / \mathrm{N})$ for each level of process parameters is measured according to the $\mathrm{S} / \mathrm{N}$ analysis. Regardless of the category of the quality characteristic, a higher $\mathrm{S} / \mathrm{N}$ ratio corresponds to the optimal level of the process parameters. ${ }^{17} \mathrm{~A}$ detailed ANOVA framework to know significance of the process parameters is also applied.

Table 1. $\mathrm{L}_{16}\left(4^{5}\right)$ orthogonal design and copper extraction recovery, $\%$.

\begin{tabular}{cccccccc}
\hline \multicolumn{4}{c}{ Factors and Levels } & \multicolumn{2}{c}{$\begin{array}{c}\text { Copper extraction } \\
\text { recovery, \% }\end{array}$} \\
\hline Test & $\mathbf{F}_{\mathbf{1}}$ & $\mathbf{F}_{\mathbf{2}}$ & $\mathbf{F}_{\mathbf{3}}$ & $\mathbf{F}_{\mathbf{4}}$ & $\mathbf{F}_{\mathbf{5}}$ & $\mathbf{C E R}_{\mathbf{1}}$ & $\mathbf{C E R}_{\mathbf{2}}$ \\
\hline $\mathbf{1}$ & 1 & 1 & 1 & 1 & 1 & 10.83 & 11.19 \\
$\mathbf{2}$ & 1 & 2 & 2 & 2 & 2 & 9.41 & 9.49 \\
$\mathbf{3}$ & 1 & 3 & 3 & 3 & 3 & 9.81 & 8.31 \\
$\mathbf{4}$ & 1 & 4 & 4 & 4 & 4 & 3.24 & 4.88 \\
$\mathbf{5}$ & 2 & 1 & 2 & 3 & 4 & 3.18 & 4.80 \\
$\mathbf{6}$ & 2 & 2 & 1 & 4 & 3 & 23.33 & 23.58 \\
$\mathbf{7}$ & 2 & 3 & 4 & 1 & 2 & 14.28 & 15.26 \\
$\mathbf{8}$ & 2 & 4 & 3 & 2 & 1 & 13.45 & 12.21 \\
$\mathbf{9}$ & 3 & 1 & 3 & 4 & 2 & 20.53 & 24.60 \\
$\mathbf{1 0}$ & 3 & 2 & 4 & 3 & 1 & 14.61 & 17.23 \\
$\mathbf{1 1}$ & 3 & 3 & 1 & 2 & 4 & 10.34 & 12.28 \\
$\mathbf{1 2}$ & 3 & 4 & 2 & 1 & 3 & 29.66 & 34.60 \\
$\mathbf{1 3}$ & 4 & 1 & 4 & 2 & 3 & 70.87 & 63.77 \\
$\mathbf{1 4}$ & 4 & 2 & 3 & 1 & 4 & 10.02 & 9.23 \\
$\mathbf{1 5}$ & 4 & 3 & 2 & 4 & 1 & 48.26 & 56.41 \\
$\mathbf{1 6}$ & 4 & 4 & 1 & 3 & 2 & 86.53 & 91.51 \\
\hline
\end{tabular}


Five different controllable process variables leaching parameters affecting the dissolution of copper from chalcopyrite concentrate such as stirring rate, acid concentration, leaching temperature, ferric ion and solid/liquid ratio and four different levels of each variable were determined (Table 2).

Table 2. Experimental factors and their levels.

\begin{tabular}{clcccc}
\hline Factor & Description & Level 1 & Level 2 & \multicolumn{2}{c}{ Level 3 Level 4 } \\
\hline $\mathbf{F}_{\mathbf{1}}$ & Stirring rate, rpm & 0 & 100 & 200 & 400 \\
$\mathbf{F}_{\mathbf{2}}$ & Acid concentration, M & 0.01 & 0.05 & 0.1 & 0.5 \\
$\mathbf{F}_{\mathbf{3}}$ & Leaching temperature, ${ }^{\circ} \mathrm{C}$ & 30 & 50 & 70 & 90 \\
$\mathbf{F}_{\mathbf{4}}$ & Ferric ion concentration, M & 0.01 & 0.02 & 0.05 & 0.1 \\
$\mathbf{F}_{\mathbf{5}}$ & Solid/liquid, g/mL & $1 / 500$ & $2 / 500$ & $3 / 500$ & $5 / 500$ \\
\hline
\end{tabular}

\section{Results and Discussion}

In order to be able to interpret the results of the experiments using multi-parameter, it is necessary to determine the $\mathrm{S} / \mathrm{N}$ (signal/noise) ratios suggested by Taguchi experimental design. Signal-to-noise ratio $(\mathrm{S} / \mathrm{N})$ shows the sensitivity of quality characteristics to noise factors. ${ }^{17}$ In general, depending on the performance characteristics, three different $\mathrm{S} / \mathrm{N}$ equations are used when quantifying the quality of the process: nominal is best, smaller is better, or larger is better. The latter is usually considered when examining the process of extracting metal ions, and the formula for this $\mathrm{S} / \mathrm{N}$ ratio approach is given in Eq. 4 below. ${ }^{13,18-21}$

In this study, for the highest desired copper dissolution efficiency (CER,\%) the $\mathrm{S} / \mathrm{N}$ ratio which gives the " larger is better " condition is given in Eq. 4.

$$
S /_{N}=-10 \log \left(\frac{1}{n} \sum_{i=1}^{n} \frac{1}{y_{i}^{2}}\right)
$$


where $\mathrm{n}$ is the number of repetitions of each experiment that were performed and $\mathrm{y}_{\mathrm{i}}$ is the observation value obtained from the its experiment.

In this study, each experiment was repeated twice and the parameters of each test determined by the Taguchi L16 experiment design plan, the $\mathrm{S} / \mathrm{N}$ ratios and means values of the results obtained from these experiments are given in Table 3.

Table 3. Taguchi $\mathrm{L}_{16}$ orthogonal experimental design. $\mathrm{S} / \mathrm{N}$ ratios and means values.

\begin{tabular}{ccccccccc}
\hline Test & $\mathbf{F}_{\mathbf{1}}$ & $\mathbf{F}_{\mathbf{2}}$ & $\mathbf{F}_{\mathbf{3}}$ & $\mathbf{F}_{\mathbf{4}}$ & $\mathbf{F}_{\mathbf{5}}$ & $\mathbf{C E R}_{\text {average }}$ & $\mathbf{S} / \mathbf{N}$ & Means \\
\hline $\mathbf{1}$ & 0 & 0.01 & 30 & 0.01 & $1 / 500$ & 11.01 & 20.8375 & 11.0122 \\
$\mathbf{2}$ & 0 & 0.05 & 50 & 0.02 & $2 / 500$ & 9.45 & 19.5081 & 9.4494 \\
$\mathbf{3}$ & 0 & 0.1 & 70 & 0.05 & $3 / 500$ & 9.06 & 19.1442 & 9.0618 \\
$\mathbf{4}$ & 0 & 0.5 & 90 & 0.1 & $5 / 500$ & 4.06 & 12.1775 & 4.0633 \\
$\mathbf{5}$ & 100 & 0.01 & 50 & 0.05 & $5 / 500$ & 3.99 & 12.0207 & 3.9906 \\
$\mathbf{6}$ & 100 & 0.05 & 30 & 0.1 & $3 / 500$ & 23.45 & 27.4043 & 23.4539 \\
$\mathbf{7}$ & 100 & 0.1 & 90 & 0.01 & $2 / 500$ & 14.77 & 23.3898 & 14.7738 \\
$\mathbf{8}$ & 100 & 0.5 & 70 & 0.02 & $1 / 500$ & 12.83 & 22.1641 & 12.8294 \\
$\mathbf{9}$ & 200 & 0.01 & 70 & 0.1 & $2 / 500$ & 22.57 & 27.0705 & 22.5696 \\
$\mathbf{1 0}$ & 200 & 0.05 & 90 & 0.05 & $1 / 500$ & 15.92 & 24.0381 & 15.9186 \\
$\mathbf{1 1}$ & 200 & 0.1 & 30 & 0.02 & $5 / 500$ & 11.31 & 21.0694 & 11.3102 \\
$\mathbf{1 2}$ & 200 & 0.5 & 50 & 0.01 & $3 / 500$ & 32.13 & 30.1377 & 32.1280 \\
$\mathbf{1 3}$ & 400 & 0.01 & 90 & 0.02 & $3 / 500$ & 67.32 & 36.5630 & 67.3211 \\
$\mathbf{1 4}$ & 400 & 0.05 & 70 & 0.01 & $5 / 500$ & 9.62 & 19.6670 & 9.6239 \\
$\mathbf{1 5}$ & 400 & 0.1 & 50 & 0.1 & $1 / 500$ & 52.34 & 34.3759 & 52.3353 \\
$\mathbf{1 6}$ & 400 & 0.5 & 30 & 0.05 & $2 / 500$ & $\mathbf{8 9 . 0 2}$ & $\mathbf{3 8 . 9 9 0 2}$ & $\mathbf{8 9 . 0 2 4 4}$ \\
\hline
\end{tabular}

As shown in Table 3, the highest copper dissolution efficiency, S/N ratios and means values were obtained in Test 16 and Test 13. When the test results were compared, the best (Test 16) and worst (Test 5) it was observed that there were huge differences between the test results and $\mathrm{S} / \mathrm{N}$ ratios and means values. Particularly in test 16 it is clear that the dissolution efficiency 
reaches $90 \%$. In Test 5, it was found that almost copper did not dissolve and dissolution efficiency was around 4\%. According to the results of this experiment, the most important parameters are mixing speed, solid/liquid ratio, acid concentration, temperature and ferric ion concentration respectively. Therefore, it can be said that mixing speed is effective and it gives better results in copper dissolution by using small amounts of oxidant with increasing acid concentration

Using Minitab 16.0 program, the significant response of $\mathrm{S} / \mathrm{N}$ ratios at certain levels of all parameters determined by Taguchi experimental design is given in Table 4 and the response of means values is given in Table 5. The determination of the effect of each factor depending on these values is shown in Figures 1 and 2.

Table 4. Response Table for Signal to Noise Ratios (the larger is better).

\begin{tabular}{cccccc}
\hline Level & $\mathrm{F}_{1}$ & $\mathrm{~F}_{2}$ & $\mathrm{~F}_{3}$ & $\mathrm{~F}_{4}$ & $\mathrm{~F}_{5}$ \\
\hline $\mathbf{1}$ & 17.92 & 24.12 & $\mathbf{2 7 . 0 8}$ & 23.51 & 25.35 \\
$\mathbf{2}$ & 21.24 & 22.65 & 24.01 & 24.83 & 27.24 \\
$\mathbf{3}$ & 25.58 & 24.49 & 22.01 & 23.55 & $\mathbf{2 8 . 3 1}$ \\
$\mathbf{4}$ & $\mathbf{3 2 . 4 0}$ & $\mathbf{2 5 . 8 7}$ & 24.04 & $\mathbf{2 5 . 2 6}$ & 16.23 \\
Delta & 14.48 & 3.21 & 5.06 & 1.75 & 12.08 \\
Rank & 1 & 4 & 3 & 5 & 2 \\
\hline
\end{tabular}

Table 5. Response Table for Means (the larger is better).

\begin{tabular}{clllll}
\hline Level & \multicolumn{1}{c}{$\mathrm{F}_{1}$} & \multicolumn{1}{c}{$\mathrm{F}_{2}$} & \multicolumn{1}{c}{$\mathrm{F}_{3}$} & \multicolumn{1}{c}{$\mathrm{F}_{4}$} & \multicolumn{1}{c}{$\mathrm{F}_{5}$} \\
\hline $\mathbf{1}$ & 8.397 & 26.223 & $\mathbf{3 3 . 7 0 0}$ & 16.884 & 23.024 \\
$\mathbf{2}$ & 13.762 & 14.611 & 24.476 & 25.228 & $\mathbf{3 3 . 9 5 4}$ \\
$\mathbf{3}$ & 20.482 & 21.870 & 13.521 & $\mathbf{2 9 . 4 9 9}$ & 32.991 \\
$\mathbf{4}$ & $\mathbf{5 4 . 5 7 6}$ & $\mathbf{3 4 . 5 1 1}$ & 25.519 & 25.606 & 7.247 \\
Delta & 46.179 & 19.900 & 20.179 & 12.614 & 26.707 \\
Rank & 1 & 4 & 3 & 5 & 2 \\
\hline
\end{tabular}


When Figures 1 and 2 were examined, the verification test was performed by considering the highest $\mathrm{S} / \mathrm{N}$ ratio and means value of the control experiments based on the results obtained from Taguchi design and Minitab 16.0 program. The copper dissolution efficiencies (CER,\%) value, $\mathrm{S} / \mathrm{N}$ ratio and means value obtained from the verification experiment were recalculated and compared with Test 16 and given in Table 6.

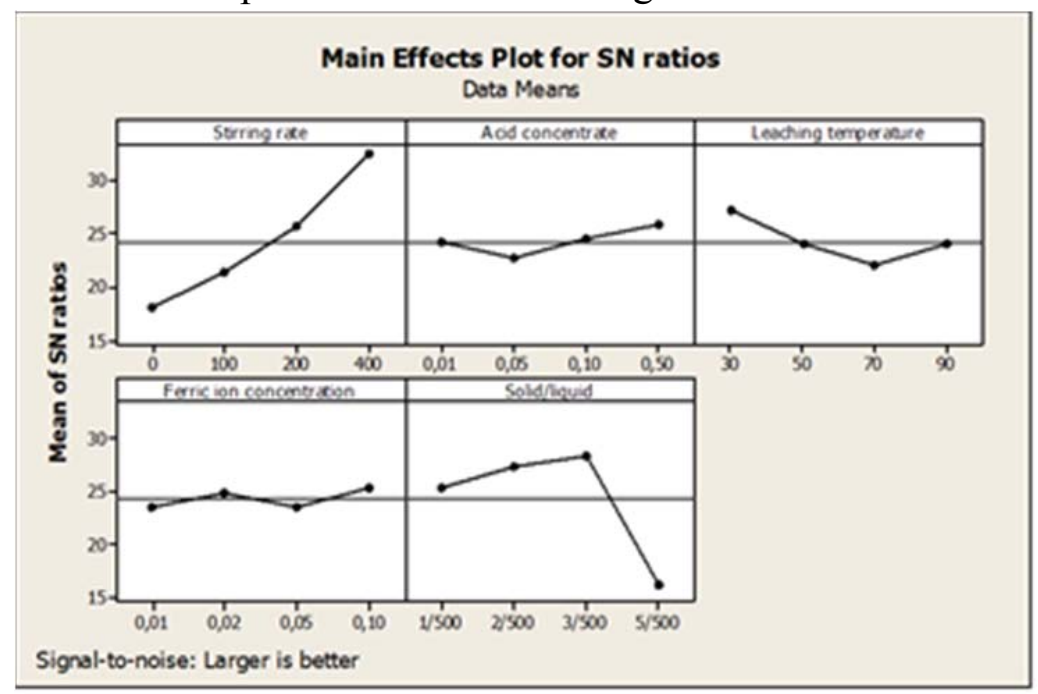

Figure 1. The effect of controllable factors on the Signal to Noise Ratios (the larger is better).

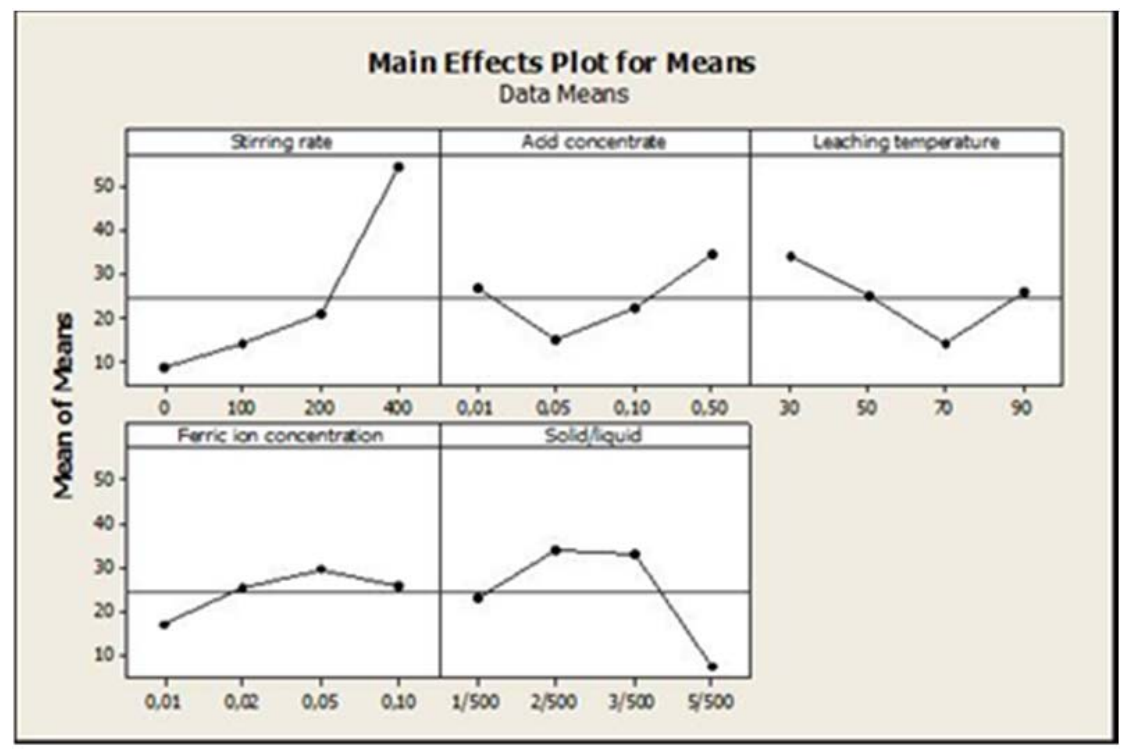

Figure 2. The effect of controllable factors on the means (the larger is better). 
Table 6. Optimum experimental conditions.

\begin{tabular}{ccccccccc}
\hline Test & $\mathbf{F}_{\mathbf{1}}$ & $\mathbf{F}_{\mathbf{2}}$ & $\mathbf{F}_{\mathbf{3}}$ & $\mathbf{F}_{\mathbf{4}}$ & $\mathbf{F}_{\mathbf{5}}$ & $\begin{array}{c}\mathbf{C E R}_{\mathbf{a v},}, \\
\mathbf{\%}\end{array}$ & $\mathbf{S} / \mathbf{N}$ & Means \\
\hline $\begin{array}{c}\text { Test 16 } \\
\text { Optimization for }\end{array}$ & 4 & 4 & 1 & 3 & 2 & 89.02 & 38.9902 & 89.0244 \\
$\begin{array}{c}\text { S/N } \\
\text { Optimization for } \\
\text { Means }\end{array}$ & 4 & 4 & 1 & 4 & 3 & & & \\
\hline
\end{tabular}

When the experimental conditions of Test 16 were analyzed with optimization studies according to the optimization experiment design obtained based on the $\mathrm{S} / \mathrm{N}$ ratios, it was observed that the stirring rate, acid concentration and leaching temperature did not change, but the ferric ion concentration and solid content increased. As a result of the evaluation of copper dissolution efficiency according to $\mathrm{S} / \mathrm{N}$ ratios and means values, it is seen that the results of Test 16 are better. This test result is clearly seen good in the optimization graph and results based on the means value. The objective of this optimization study is to achieve the best dissolution efficiency. Therefore, the aim of the studies using Taguchi experimental design is to reach optimal results. This result can sometimes be any of the existing experiments given in the design and sometimes it is the result of the experiment proposed by the design. ${ }^{22,23}$ Therefore, it is necessary to perform the verification test determined according to $\mathrm{S} / \mathrm{N}$ and Means values. In this study, optimum results were obtained with Test 16 from the experiments performed in design. The test conditions given by the Means values given in Table 6 and Test 16 conditions are the same. In addition, ANOVA method was applied to the results and the contribution percentage of each factor was determined (Table 7). 
Table 7. Analysis of variance for copper extraction recovery (CER, \%).

\begin{tabular}{|c|c|c|c|c|c|c|c|}
\hline Factor & $\begin{array}{c}\text { DoF } \\
\text { F }\end{array}$ & $S S_{\mathrm{F}}$ & $\rho_{F}(\%)$ & $\begin{array}{c}F- \\
\text { value }\end{array}$ & $\begin{array}{c}P- \\
\text { value }\end{array}$ & $S S_{\mathrm{T}}$ & $V_{\text {Er }}$ \\
\hline $\begin{array}{c}\text { Stirring rate, } \\
\text { rpm }\end{array}$ & 3 & 5180.77 & 57.40939 & 5.40 & 0.000 & 9019.03 & 0.166315 \\
\hline $\begin{array}{c}\text { Acid } \\
\text { concentration, } M\end{array}$ & 3 & 830.96 & 9.180145 & 0.41 & 0.034 & & \\
\hline $\begin{array}{c}\text { Leaching } \\
\text { temperature, }{ }^{\circ} \mathrm{C}\end{array}$ & 3 & 824.26 & 9.105857 & 0.40 & 0.125 & & \\
\hline $\begin{array}{c}\text { Ferric ion } \\
\text { concentration, } M\end{array}$ & 3 & 338.33 & 3.718027 & 0.16 & 0.349 & & \\
\hline $\begin{array}{l}\text { Solid/liquid, } \\
\text { g/mL }\end{array}$ & 3 & 1844.71 & 20.42027 & 0.03 & 0.010 & & \\
\hline
\end{tabular}

Here, $D o F_{F}$ : the level of freedom for each factor; $S S_{\mathrm{F}}$ : factorial sum of squares of factors; $\rho_{\mathrm{F}}(\%)$ : percentage of each factor; $S S_{\mathrm{T}}$, sum of squares; $V_{\mathrm{Er}}$ : variance of error. When analyzing ANOVA results, a large value of Fisher (F-test) with a small P-value (i.e.p<0.05) indicate that the model is statistically significant, whereas the values greater than 0.1 show that the model terms are not significant. ${ }^{24}$ It was found that the most effective parameter was the stirring rate and the less effective parameter was the ferric ion concentrate under the experimental conditions made with the selected parameters.

\section{Conclusions}

This study was aimed to identify the optimal and most influencing leaching parameters of copper extraction from chalcopyrite concentrate in effect of ferric chloride under hydrochloric acid by conducting minimum number of experiments using Taguchi orthogonal array. Analysis of variance (ANOVA) technique indicated that the most effective parameter was the stirring rate and the less effective parameter was the ferric ion concentrate. In this study, optimization for Means showed that the optimum 
experimental conditions were found to be a solid-to-liquid ratio of $2 \mathrm{~g} / 500 \mathrm{~mL}$, a ferric chloride concentration of $0.05 \mathrm{M}$, a leaching temperature of $30{ }^{\circ} \mathrm{C}$, acid concentration of $0.5 \mathrm{M}$, and a stirring speed of $400 \mathrm{rpm}$. Under these conditions, copper extraction from chalcopyrite of approximately $89 \%$ was achieved.

\section{References}

1. Córdoba, E.M.; Muñoz, J.A.; Blázquez, M.L.; González, F.; Ballester, A. Leaching of chalcopyrite with ferric ion. Part I: General aspects. Hydrometallurgy 2008, 93(3-4), 81-87.

2. Dutrizac, J.E. The kinetics of dissolution of chalcopyrite in ferric ion media. Metall. Trans. B 1978, 9(3), 431-439.

3. Antonijević, M.M.; Janković, Z.D.; Dimitrijević, M.D. Kinetics of chalcopyrite dissolution by hydrogen peroxide in sulphuric acid. Hydrometallurgy 2004, 71(3-4), 329-334.

4. Aydogan, S.; Ucar, G.; Canbazoglu, M. Dissolution kinetics of chalcopyrite in acidic potassium dichromate solution. Hydrometallurgy 2006, 81(1), 45-51.

5. Prasad, S.; Pandey, B. D. Alternative processes for treatment of chalcopyrite - a review. Miner. Eng. 1998, 11(8), 763-781.

6. Hidalgo, T.; Kuhar, L.; Beinlich, A.; Putnis, A. Kinetic study of chalcopyrite dissolution with iron (III) chloride in methanesulfonic acid. Miner. Eng. 2018, 125, 66-74.

7. Antonijević, M.M.; Janković, Z.; Dimitrijević, M. Investigation of the kinetics of chalcopyrite oxidation by potassium dichromate. Hydrometallurgy 1994, 35(2), 187-201.

8. Liddicoat, J.; Dreisinger, D. Chloride leaching of chalcopyrite. Hydrometallurgy 2007, 89(3-4), 323-331.

9. Padilla, R.; Vega, D.; Ruiz, M. C. Pressure leaching of sulfidized chalcopyrite in sulfuric acid-oxygen media, Hydrometallurgy 2007, 86(1-2), 80-88. 
10. Turan, M. D.; Altundoğan, H. S. Leaching of chalcopyrite concentrate with hydrogen peroxide and sulfuric acid in an autoclave system. Metall. Mater. Trans. B 2013, 44(4), 809-819.

11. Dutrizac, J.E. Elemental sulphur formation during the ferric chloride leaching of chalcopyrite. Hydrometallurgy 1990, 23(2-3), 153-176.

12. Bayca, S.U.; Kisik, H. Optimization of leaching parameters of aluminum hydroxide extraction from bauxite waste using the Taguchi method. Environ. Prog. Sustain. 2018, 37(1), 196-202.

13. Merad, N. S.; Belkhouche, N. Use of Taguchi's DOE for process optimization of Co (II) extraction in chloride medium by Aliquat 336. Euro-Mediterr. J. Environ. Integr. 2019, 4(1), 32.

14. Copur, M.; Kizilca, M.; Kocakerim, M.M. Determination of the optimum conditions for copper leaching from chalcopyrite concentrate ore using Taguchi method. Chem. Eng. Commun. 2015, 202(7), 927-935.

15. Abali, Y.; Bayca, S.U.; Arisoy, K.; Vaizogullar, A.I. Optimization of dolomite ore leaching in hydrochloric acid solutions. Physicochem. Probl. Miner. Process. 2011, 46(1), 253-262.

16. Çopur, M.; Özmetin, C.; Özmetin, E.; Kocakerim, M.M. Optimization study of the leaching of roasted zinc sulphide concentrate with sulphuric acid solutions. Chem. Eng. Process 2004, 43(8), 1007-1014.

17. Roy, R.K. A Primer on the Taguchi Method. Van Nostrand Reinhold, New York, 1990.

18. Barrado, E.; Vega, M.; Pardo, R.; Grande, P.; Del Valle, J.L. Optimisation of a purification method for metal-containing wastewater by use of a Taguchi experimental design. Water Res. 1996, 30(10), 2309-2314.

19. Kaminari, N.; Schultz, D.; Ponte, M.; Ponte, H.; Marino, C.; Neto, A. Heavy metals recovery from industrial wastewater using Taguchi method, Chem. Eng. J. 2007, 126 (2-3), 139-146.

20. Mondal, S.; Paul, B.; Kumar, V.; Singh, D.; Chakravartty, J.K. Parametric optimization for leaching of cobalt from Sukinda ore of lateritic origin-A Taguchi approach. Sep. Purif. Technol. 2015, 156, 827-834.

21. Pundir, R.; Chary, G.H.V.C.; Dastidar, M.G. Application of Taguchi method for optimizing the process parameters for the removal of copper 
and nickel by growing Aspergillus sp. Water Resour. Ind. 2018, 20, 8392.

22. Yılmaz, V.; Dilipak, H.; Sarıkaya, M.; Yılmaz, C.Y.; Meral, G. Frezeleme işlemlerinde titreşimi ve yüzey pürüzlülüğünü etkileyen parametrelerin optimizasyonu. S.D.Ü. Teknik Bilimler Dergisi 2014, 4(1), 37-44.

23. Duzyol, S. Taguchi deneysel tasarım metodu kullanılarak Karadon (Zonguldak) kömürünün yağ aglomerasyonu davranışının incelenmesi. Ç.Ü. Müh. Mim. Fak. Dergisi 2016, 31(2), 77-84.

24. Korbahti, B.K.; Tasyurek, S. Electrochemical oxidation of ampicillin antibiotic at boron-doped diamond electrodes and process optimization using response surface methodology. Environ. Sci. Pollut. Res. 2015, 22(5), 3265-3278. 